\title{
The relationship between air pollution caused by fungal spores in Mexicali, Baja California, Mexico, and the incidence of childhood asthma
}

\author{
R. A. de la Fuente-Ruiz ${ }^{1}$, M. Quintero-Núñez ${ }^{2}$, S. E. Ahumada ${ }^{2}$ \\ \& R. O. García ${ }^{2}$ \\ ${ }^{1} U A B C$, Mexicali, $B C$, Mexico \\ ${ }^{2}$ Department of Environment of the Institute of Engineering, \\ $U A B C, B C$, Mexico
}

\begin{abstract}
Air pollution has affected human life progressively since its sources of origination. It is present in all cities around the world. It has caused harm to humans and other living organisms. This situation has led studies to determine the impact of concentrations of air pollutants in the respiratory ailments. Mexico has developed similar investigations, but unlike other countries' advanced studies on pollutants aerobiology, Mexico's studies have not been conducted in depth, and there is virtually no research work that identifies the air pollutants of fungal spores and their association with respiratory disorders in children. The purpose of this article is to analyze the relationship between air pollution by fungal spores, and the incidence of childhood asthma in Mexicali, Baja California, Mexico. Diagnostics of asthma on children living in the city of Mexicali that received medical care were studied. The records of weather and climatic variables were provided by the Department of Meteorology at the Engineering Institute of UABC. The data of air pollution caused by fungal spores were obtained in three monitoring stations with collectors' rotation and impact of sampling. Mainly four groups of different spores (Alternaria sp., Cladosporiun $s p$., Bipolaris and Stemphylium) were registered in the atmosphere of Mexicali, with an average of 515 spores $/ \mathrm{m}^{3}$ and a standard deviation of 248 spores $/ \mathrm{m}^{3}$. The average annual relative humidity was $42.3 \%$. The average temperature showed two different facets; a hot season with temperatures between $22^{\circ} \mathrm{C}$ and $44^{\circ} \mathrm{C}$, and a cold season with temperatures between $8.9^{\circ} \mathrm{C}$ and $22^{\circ} \mathrm{C}$. The incidence of childhood asthma presented a rate twice the national average (505 cases/one hundred thousand children). The multiple linear regression model proposed showed a significant relationship with a $\mathrm{R} 2=0.86(\mathrm{p}=0.5)$, which established a direct association between air pollution by fungal spores, and the incidence of childhood asthma.
\end{abstract}

Keywords: childhood asthma, aerobiological contamination, fungal spores, asthma and weather conditions, Mexicali. 


\section{Introduction}

Air pollution is a problem impacting all cities around the world, especially those places with a high production of pollutants due to technological development. It causes various diseases in the respiratory system. The concern about the harmful effects caused by air pollution is higher every day; an affection that has led to investigate the relation between the concentrations of air pollutants and respiratory tract problems in different age groups, as well as to find meaningful relationships in epidemiological terms [1,2]. In such studies are taken in consideration different concentrations of air pollutants, weather variations, time of exposure and its health impacts on different age groups [3, 4].

Within this group, it is of great interest to address the effects of aerobiological pollutants in children which asthma is presented as a major disease caused by these types of pollutants that show the immune response characteristic to the allergens that float in the air [5]. In atopic children is usually presented as a chronic disease, which can last up to adolescence, and in some cases to adulthood which represents a problem of public health [6]. Pulimood (2008) conducted in 2002 an investigation in the United Kingdom on children during an increased in medical consultations due to asthma attacks which exceeded the usual medical consultation for this type of attacks, and found a direct correlation between levels of atmospheric pollution by Alternaria and Cladosporium spores, and the increase in the incidence and severity of the symptoms [7]. In Mexico similar correlations have been obtained [8-10]. Unfortunately, studies covering the weather conditions and aerobiological pollutants focus on respiratory infections have not been performed in Mexicali, Baja California, Mexico as of today [11] and it may be said that there are no conclusive studies on how to analyze the relationship between the atmospheric concentration of particles of biological origin such as pollen or fungal spores and its harmful effect on the airways in children.

Mexicali is the capital of state of Baja California, Mexico, with a population of approximately eight hundred and fifty-five thousand people [12], located on the northern border of Mexico adjacent to Imperial Valley, California, United States of America, sharing the same atmospheric basin [13]. On the other hand its location north of the Sonora's desert determines an extreme climate with long summers, with maximum temperatures reaching $42^{\circ} \mathrm{C}$ to record temperatures of up to $53^{\circ} \mathrm{C}$, contrasting with short winters with low temperatures that can reach below $7^{\circ} \mathrm{C}$, with a desert ecosystem that benefits from the tributaries of the Colorado River which contributes to the development of a strong agricultural activity, whose main crops are; wheat, barley, cotton, alfalfa, oats, sesame, safflower, sorghum forage, rye grass, vegetables and crops, and in a smaller scale watermelons, cantaloupes, corn, grapes, beans and prickly pear [14]. The objective of this study was to analyze the relationship between air pollution caused by fungal spores and the rising incidence of childhood asthma in the city of Mexicali. 


\section{Material and methods}

The period of investigation covered one year (1/09/2004 to 31/08/2005). The studied population was composed by three different children's ages: One year and under, from 1 to 4 years, and 5 to 14 years old, all residents in different areas of the city of Mexicali and who received medical attention in governmental health facilities. The data was obtained from medical reports of all medical units of the Mexican Institute of Social Security (IMSS), Institute of Social Security of the State Workers (ISSSTE), Institute of Social Security for the State Workers of Baja California (ISSSTECALI), and Secretary of Health and Assistance (SSA). It was considered the total number of medical consultations from the first time by bronchial asthma among children between the ages selected. The cases were identified by age group and sex, according to medical diagnostics focused on the weekly report of new cases of disease (SUIVE) provided by the management of Epidemiology of the Health Secretariat of the State of BC, following the International Classification of Diseases, in its tenth revision (ICD-10). To facilitate the handling of official reports, were consolidated into a single record cases of asthma and status asthmaticus (CIE10: J45 and J46).

\subsection{Meteorological data and air pollution}

The meteorological variables were selected with an epidemiological approach, taking in consideration the records of the Relative Humidity Average (RHA) and Monthly Mean Temperature (MMT) data that was provided daily by the Department of Meteorology of the Institute of Engineering at the Universidad Autonoma de Baja California (UABC).

The atmospheric concentration of fungal spores data was obtained from the study conducted by Quintero (2006) [15], based on a sampling system using three monitoring stations, and strategically distributed in the city of Mexicali. The sampling of air pollutants was performed using a collector of rotation and impact type, Rotorod 40. It was estimated the rate of lung exposure (RLE) for fungal spores, considering the average exposure for 24 hours, as the product of the average concentration of spores $/ \mathrm{m}^{3}$ (ACS) in relation to the average daily volume of breathing in (AVB): RLE $=[(\mathrm{ACS})(\mathrm{AVB})]$.

\subsection{Statistical analysis}

A descriptive analysis was performed from the obtained data: atmospheric concentration of fungal spores, the monthly mean temperature (MMT), relative humidity average (RHA) and the incidence of childhood asthma by age and sex, using graphic time series and frequency distribution for quality control. It was performed an independent analysis of the relationship between each of the variables proposals and cases of childhood asthma, taking into account each of the three age groups for the study. Finally, it was made an analysis focusing all cases of childhood asthma in a single group having its variations by sex. To interpret the association between the variables studied, it was designed a multiple linear regression model which allowed a reduction to a minimum statistical error 
and limitation of partiality. The handling of the data was performed with SPSS 12.

\section{Results}

During the years of the study there were a total of 1,212 new cases of childhood asthma registered, with a rate of 505 cases/one hundred thousand children, of whom $57 \%$ were males. The cases of asthma were more frequent in the 5 to 14 years age group (63\%), with 766 cases, and in second place, the 1 to 4 group aged $(31 \%$,) and 373 cases, and with less involvement the children age of one year under, with 73 cases (six percent). The overall incidence of asthma showed a higher frequency in the months of March with 125 cases, 102 cases in June, 130 cases in October, 143 cases in November and December with 156 cases, as shown in table 1.

Table 1: $\quad$ Incidence of childhood asthma by age group and sex.

\begin{tabular}{|c|c|c|c|c|c|c|}
\hline Months & $>1$ & 1 to 4 & 5 to 14 & Total & \multicolumn{2}{|c|}{ Sex } \\
\cline { 5 - 7 } & & & & & $F$ & M \\
\hline S2004 & 2 & 31 & 63 & 96 & 50 & 57 \\
\hline O2004 & 10 & 34 & 86 & 130 & 57 & 72 \\
\hline N2004 & 8 & 49 & 86 & 143 & 51 & 77 \\
\hline D2004 & 6 & 66 & 84 & 156 & 47 & 68 \\
\hline E2005 & 6 & 37 & 55 & 98 & 42 & 48 \\
\hline F2005 & 6 & 3 & 67 & 76 & 40 & 46 \\
\hline M2005 & 7 & 50 & 68 & 125 & 54 & 76 \\
\hline A2005 & 5 & 27 & 58 & 90 & 38 & 49 \\
\hline M2005 & 9 & 23 & 67 & 99 & 39 & 52 \\
\hline J2005 & 8 & 29 & 65 & 102 & 46 & 62 \\
\hline J2005 & 3 & 15 & 33 & 51 & 25 & 39 \\
\hline A2005 & 3 & 9 & 34 & 46 & 34 & 43 \\
\hline Total & 73 & 373 & 766 & 1212 & 523 & 689 \\
\hline
\end{tabular}

Source: Health Secretary of Mexico 2006.

The incidence of asthma in general showed a cyclical behavior of bimodal type, with an initial plateau in December (156 cases), and a second plateau in March with 121 cases.

Regarding the atmospheric concentration of fungal spores, mainly 4 different groups of spores were identified, they were selected by its atmospheric concentration and its epidemiological significance; Alternaria sp., Cladosporiun sp., Bipolaris y Stemphylium, table 2. The general behavior of the atmospheric concentration of fungal spores with a cyclical behavior, showed an increased in concentration spores $/ \mathrm{m}^{3}$ in three stages: the first in March (503 spores $/ \mathrm{m}^{3}$ ), the 
Table 2: $\quad$ Spores found in the sampling of a year, in Mexicali`s atmosphere.

\begin{tabular}{|l|c|c|c|c|c|}
\hline Months & Alternaria & Cladosporium & Stemphylium & Bipolaris & Total \\
\hline S2004 & 107 & 0 & 10 & 63 & 180 \\
\hline O2004 & 62 & 85 & 12 & 129 & 288 \\
\hline N2004 & 127 & 94 & 56 & 78 & 355 \\
\hline D2004 & 29 & 110 & 168 & 35 & 342 \\
\hline E2005 & 300 & 287 & 201 & 82 & 870 \\
\hline F2005 & 171 & 151 & 251 & 31 & 604 \\
\hline M2005 & 278 & 86 & 96 & 43 & 503 \\
\hline A2005 & 146 & 133 & 40 & 23 & 342 \\
\hline M2005 & 186 & 156 & 67 & 56 & 465 \\
\hline J2005 & 167 & 172 & 48 & 84 & 471 \\
\hline J2005 & 443 & 126 & 65 & 147 & 781 \\
\hline A2005 & 1203 & 303 & 183 & 297 & 1986 \\
\hline Total & 3219 & 1703 & 1197 & 1068 & 7187 \\
\hline
\end{tabular}

Source: Atmospheric sampling 2006.

second was in August (986 spores $\left./ \mathrm{m}^{3}\right)$, and the third in January $\left(870\right.$ spores $/ \mathrm{m}^{3}$ ) to February $\left(604\right.$ spores $\left./ \mathrm{m}^{3}\right)$. The descriptive statistics showed that the atmosphere of Mexicali, presents an annual average of 515 spores $/ \mathrm{m}^{3}$ with a standard deviation (SD) of 248 spores $/ \mathrm{m}^{3}$, and an average daily. As a result of calculating the rate of lung exposure to fungal spores (RLE), which may happen in a typical day, there is a possibility that on average 164 spores/day make contact with the mucus of the airways. Concentrations which become very important considering the potential of pathogenic fungi spores, and the atmospheric concentration limit to produce a case clinical of asthma.

$$
\mathrm{RLE}=[(\mathrm{ACS})(\mathrm{AVB})]
$$

As a result

$$
\operatorname{RLE}=\left[\left(19 \mathrm{spores} / \mathrm{m}^{3}\right)\left(8.64 \mathrm{~m}^{3} / \text { day }\right)\right]=164 \text { spores } / \text { day }
$$

The annual relative humidity average (RHA) was $42.3 \%$, with monthly range from $25 \%$ to $63 \%$ and an upward trend from august to February with a record of increase in humidity as shown in table 3 .

The monthly mean temperature (MMT) records showed two different facets, one in the cold season that starts in November and continues until February, reached its minimum $8^{\circ} \mathrm{C}$ average, and a warm season, which starts virtually in may $\left(28^{\circ} \mathrm{C}\right)$, increasing gradually up to august $\left(35^{\circ} \mathrm{C}\right)$, with a record peak in the month of July that reached $44^{\circ} \mathrm{C}$, as shown in table 4 .

This means that in a typical day, a child resident in the city of Mexicali has an $86 \%$ probability to present the clinical symptoms of bronchial asthma.

The application of the multiple linear regression model was developed to analyze the behavior of the incidence of childhood asthma based on the epidemiological variables studied (monthly average spores $/ \mathrm{m}^{3}$, MMT and RHA) reflects a percentage of reliability with an $\mathrm{R}^{2}=0.86(\mathrm{P}<.05)$. 
Table 3: $\quad$ Relative humidity averages in Mexicali.

\begin{tabular}{|c|c|c|c|}
\hline Months & $\begin{array}{c}\text { R.H. } \\
\text { Maximum }\end{array}$ & $\begin{array}{c}\text { R.H. } \\
\text { Minimum. }\end{array}$ & $\begin{array}{c}\text { R.H. } \\
\text { Average }\end{array}$ \\
\hline S2004 & 57.9 & 15.3 & 32.9 \\
\hline O2004 & 66 & 23.5 & 42.9 \\
\hline N2004 & 72.8 & 26.4 & 49 \\
\hline D2004 & 74 & 30.8 & 52.5 \\
\hline J2005 & 83.2 & 37.9 & 62 \\
\hline F2005 & 93.2 & 33.5 & 63.6 \\
\hline M2005 & 61.2 & 37.8 & 44.5 \\
\hline A2005 & 51.8 & 13.7 & 28.9 \\
\hline M2005 & 53.7 & 14.3 & 30.9 \\
\hline J2005 & 48.1 & 12.5 & 25.8 \\
\hline J2005 & 62.1 & 14.4 & 34.1 \\
\hline A2005 & 69.9 & 21.7 & 41.2 \\
\hline
\end{tabular}

Source: Department of Meteorology of the Institute of Engineering, UABC, 2006.

Table 4: $\quad$ Monthly mean temperature in Mexicali.

\begin{tabular}{|c|c|c|c|}
\hline & $\begin{array}{c}\mathrm{T}^{\mathrm{o}} . \\
\text { Maximum. }\end{array}$ & $\begin{array}{c}\mathrm{T}^{\mathrm{o}} . \\
\text { Minimum. }\end{array}$ & $\begin{array}{c}\mathrm{T}^{\mathrm{o}} . \\
\text { Average }\end{array}$ \\
\hline $\mathrm{S} 2004$ & 37.9 & 22.6 & 30.25 \\
\hline $\mathrm{O} 2004$ & 32.9 & 17.6 & 25.25 \\
\hline $\mathrm{N} 2004$ & 24.1 & 10.7 & 17.4 \\
\hline $\mathrm{D} 2004$ & 21.7 & 8.9 & 15.3 \\
\hline $\mathrm{J} 2005$ & 22.3 & 10.6 & 16.45 \\
\hline $\mathrm{F} 2006$ & 22.3 & 11.4 & 16.85 \\
\hline $\mathrm{M} 2006$ & 27.7 & 14.0 & 20.85 \\
\hline $\mathrm{A} 2005$ & 32.5 & 15.0 & 23.75 \\
\hline $\mathrm{M} 2005$ & 36.0 & 20.9 & 28.45 \\
\hline $\mathrm{J} 2005$ & 39.7 & 23.4 & 31.55 \\
\hline $\mathrm{J} 2005$ & 44.0 & 28.6 & 36.3 \\
\hline A2005 & 42.8 & 28.7 & 35.75 \\
\hline
\end{tabular}

Source: Department of Meteorology of the Institute of Engineering of the UABC, 2006. 


\section{Discussions}

There are several epidemiological studies realized at a number of cities in Mexico's northern border, where the relationship between changes in human health and the concentration of air pollutants was analyzed, which only few considered; aerobiological pollutants and the increased incidence of childhood asthma in the specified form were found $[16,17]$. It may be said that there are virtually no studies that specifically analyzed the air pollutants such as fungal spores and the incidence of childhood asthma, despite the high concentrations of air pollutants of this type, reported in taxonomic studies carried out in different parts of Mexico, [18-20]. Papers published in other regions such as Europe and USA, analyzed this type of pollutant and its potential to cause health damage [21-24].

Mexicali is a border town in northern Mexico, with an economy based on the in bond industry and agriculture, where plants are grown mainly for family of Gramineas such as wheat or corn, whose harvests leaves are easily invaded by fungi. On the other hand the waste of most agricultural products are a fertile ground for the incubation of fungi, as Alternaria and Cladosporium [25], coupled with weather and specific topographical conditions (on average 11 meters below sea level), contribute to an higher concentration of fungal spores in the atmosphere that can be associated with the high index of lung exposure of 164 spores/day, combined with the type of spores observed and its association with the incidence of asthma. Special Comment demand registration of 1986 spores $/ \mathrm{m}^{3}$ observed in August, which takes place in the fallowing of farmland, which involves the removal of land by releasing the Ascospores and Conidias, specialized structures that were adapted by fungi order to remain in latent form in different time periods in dry soil, waiting for moisture and a biological substrate to reproduce and germinate.

Halomen (1997), established a direct relationship between the spores of Alternaria and childhood asthma, in similar studies which showed a positive relationship between the atmospheric concentration of spores, and the presence of specific alterations of human health [26-28], which helps to explain the presence of a rate of childhood asthma 505/one hundred thousand children, that represents approximately the national average two folded [29]. The largest percentages of these were observed in males at the age before puberty, as it was reported by Sears (2008) in its study on the epidemiology of asthma [30].

By observing the incidence of childhood asthma it has been appreciated a bimodal type behavior with a well-defined subsequent relationship to the maximum levels of air pollution by fungus spores. The subsequent relationship is explainable as a delayed response caused by the amount of dispersion time and deposition in the lung epithelium, [31], joined to a physio-pathological response with a latency period of 5 days on average, and a belated reaction family, which could last up to 7 days after contact, before the severity of the clinical data required a visit to a physician [32]. In relation to the application by sex shows a higher percentage of males, similar to the reported in national records. 
Finally the implementation of the proposed regression model showed a significant relationship with an $\mathrm{R} 2=86(\mathrm{p}=0.05)$ among the epidemiological variables (average relative humidity, temperature and atmospheric concentration of fungal spores $/ \mathrm{m}^{3}$ ) and the increase in the incidence of childhood asthma in the city of Mexicali

\section{Conclusions}

This study provides an analysis of the impact of air pollution caused by fungal spores of Alternaria, Cladosporiun, Bipolaris and Stemphylium on children's respiratory system in Mexicali, as a response to a combination of the unique characteristics of Mexicali and its Valley such as extreme temperatures, moisture levels, diverse crops plantation, type of plants and bushes and the topographical features of the region. The results of the linear regression model proposed, allowed to establish a $86 \%$ probability, a positive relationship between levels of atmospheric pollution by fungal spores, the increase in the temperature rates, air humidity and behavior of the incidence of childhood asthma.

It is important to note that the findings of air pollutants by fungal spores encountered in this work derived from the only study carried out in the region.

\section{References}

[1] Rosales, C.J.A., Torres, M.V.M., Olaiz, F.G. \& Borja, A.V.H., Los efectos agudos de la contaminación del aire en la salud de la población: evidencia de estudios epidemiológicos. Salud Pública Méx., 43, pp.544555, 2001.

[2] Romero, P.M., Más, B.P., Lacasaña, N.M., Téllez Rojo, S.M.M., Aguilar, V.J. \& Romieu, I., Contaminación atmosférica, asma bronquial e infecciones respiratorias agudas en menores de edad de La Habana. Salud Pública Mex, 46, pp. 222-233, 2004.

[3] Dales, R.E., Cakmak, S., Judek, S., Dan, T., Coates, F., Brook, J.R. \& et al., Influence of outdoor aeroallergens on Hospitalization for asthma in Canada. Asthma and immunology, 10 (1016), pp. 303-306, 2004.

[4] Chardon, B., Lefranc, A., Granados, D. \& Gremy, I., Air pollution at doctors' house call for respiratory diseases in the Greater Paris area. Occupational\& Environmental Medicine, 64 (5), pp. 320-324, 2007.

[5] Van, H.C.L., Maes, T. Joos, G.F. \& Tournoy, K.G., Chronic inflammation in asthma: a contest of persistence vs resolution. Allergy, 63, pp. 1095 1109, 2008.

[6] Spahn, J.D. \& Covar, R., Clinical assessment of asthma progression in children and adults. J. Allergy clin immunol, 121 (39), pp. 548-557, 2008.

[7] Pulimood, B.T., Corden, M.J., Bryden, C., Sharples, L. \& Nasser, M.S., Epidemic asthma and the role of the fungal mild Alternaria alternate. $J$ Allergy Clin Immunol, 120 (3), pp. 610-617, 2008.

[8] Hernández, C.L., Téllez, R.M.M., Sanín, A.L.H., Lacasaña, N.M., Campos, A. \& Romieu, I., Relación entre consultas de urgencias por 
enfermedad respiratoria y contaminación atmosférica en Ciudad Juárez, Chihuahua. Salud Pública Méx., 42, p.p. 288-297, 2000.

[9] Romieu, I., Meneses, F. \& Ruiz, R., Effects of air pollution on the respiratory health asthmatic children living in México City. Am. J Respir Crist Med., 154, pp. 300-.307, 2007.

[10] Villa, I.M., Vargas, Z.J., Gortáre, M.P., Flores. S.A., Badii, Z.M., González, H.R. \& et all., Efectos de la contaminación atmosférica sobre la población infantil en Cd.. Obregón Sonora. ITSON-DIEP., 3 (10), pp. 1928, 2001.

[11] Rosas, I., Mc Cartney, H.A., Calderón, C., Lacey, J., Chapela, R. \& Ruiz, V.S., Analysis of the relationships between environmental factors (aeroallergens, air pollution, and weather) and asthma emergency admissions to a hospital in Mexico City. Allergy, 53 (4), pp. 394-401, 1998.

[12] Sistema Nacional de Información Estadística y Geografía, México. www.inegi.gob.mx/lib/buscador/ busqueda.aspx.

[13] Sweedler, A., Fertig M., Collins, K. \& Quintero, N.M., Air Quality in California-Baja California. Border Region, SCERP: California US, 3457, 2003.

[14] Vengas, F.R. Manual para el reconocimiento de los árboles y arbustos más comunes en la ciudad de Mexicali, UABC: Baja California México, pp. 65-75, 1991.

[15] Quintero, N.M., Ahumada, V.S.E. \& Núñez, P.P.G. Mapeo Polínico. Cuarto reporte del proyecto. Online. http://scerp.org/apps/cont.mgt/doc files/ Mapa PolinicoMexicali. \%202004-2\%20 (espa_ol).pdf. Mexicali.

[16] Reyna, C.M.A., Quintero, N.M. \& Collins, K. Correlation Study of the Association of $\mathrm{PM}_{10}$ with the Main Respiratory Diseases in the Populations of Mexicali, Baja California and Imperial County, California. Revista Mexicana de Ingeniería Biomédica, 26 (1), pp. 22-36, 2005.

[17] Hernández, C.L., Barraza, V.A., Ramírez, A.M., Moreno, M.H. \& Miller, P., Carbajal-Arroyo, L.A. Romieu, I., Morbilidad infantil por causas respiratorias y su relación con la contaminación atmosférica en Ciudad Juárez, Chihuahua, México. Salud Pública Mex., 49, pp. 27-36, 2007.

[18] Arrequín, S.M.L., Fernández, N.R., Palacios, CH.R. \& Quiroz, G.L. Morfología de las esporas de Pteridofitas. Isosporas del estado de Querétaro, México. Poli botánica, 2, pp. 10-60, 1996.

[19] Gamboa, A.M.M., Escalante, E.F. Alejos, G.F., Garcia, S.K., Delgado, L.G. \& Peña, R.L.M. Natural Zinniol derivatives from Alternaria Tagetica. Isolation, synthesis and structure-activity correlation. Journal of Agricultural and Food Chemistry, 50, pp. 1053-1058, 2000.

[20] Gamboa, A.M.M., García, S.K., Alejos, G.F., Escalante, E.F., Delgado, L.G. \& Peña, R.L.M. Tagetolone and tagetenolone, two phytotoxic polyketides from Alternaria T., Journal of Agricultural and Food Chemistry, 49, pp. 1228-1232, 2001.

[21] Gioulekasn, D., Damialis, A., Papakosta, D., Spieksma, S., Giouleka, P. \& Patakas, D. Allergenic fungi spore records (15 years) and sensitization in 
patients with respiratory allergy in Thessaloniki-Greece. J Invest Allergol Clin Immunol, 14 (3), pp. 225-231, 2004.

[22] Bartra, T.J., Mapa Fúngico y estudio multicéntrico de sensibilización a Hongos en Cataluña. Alergol Inmunol Clin, 18 (3), pp. 106-121, 2003.

[23] Sanz, C., Isidro, G.M., Dávila, I., Moreno, E., Laffond, E. \& Lorente F., Analysis of Polymorphisms in Patients with Asthma. J. Investig Allergol Clin Immunol, 16 (6), pp. 331-337, 2006.

[24] Ghosh, N., Camacho, R., Saadeh, C., Gaylor, M. \& Smith, D. W., Study on the Fungal Aeroallergen Concentration in the Texas Panhandle Using a Buckard Volumetric Spore Trap. J Clin Alergia Immunol, 113, S91, 2004.

[25] Sabariego, R.S., Díaz de la Guardia G.C., Alba S.F. (2004) Estudio aerobiológico de los conidios de Alternaria y Cladosporium en la atmósfera de la ciudad de Almería (SE de España). Rev Iberoam Micol; 21: $121-127$

[26] Halonen, M., Stern, D.A., Wright, A.L., Taussig, L.M. \& Martinez, F.D. Alternaria as a major allergen for asthma in children raised in a desert environment Am. J. Respir. Crit. Care Med, 155 (4), pp.1356-1361, 1997.

[27] Del Palacio, A. P.S.M., Arbi, A., Valle, A., Perea, S. \& Rodríguez, N.A., Bipolares en un enfermo español con sinusitis alérgica crónica. España. Rev Iberoam Micol, 14, pp.191-193, 1997.

[28] Gómez, S.A., Torres, R.J.M., Alvarado, R.E., Mojal, G.S. \& Belmonte, S.J., Seasonal Distribution of Alternaria Aspergillus, Cladosporium and Penicillium Species Isolated in Homes of Fungal Allergic Patients. $J$ Investig Clin Inmunol, 16 (6), pp. 357-363, 2006.

[29] Secretaria de Salud (S.S.). Office of Sistema Nacional de Vigilancia Epidemiológica, Mèxico DF. www.dgepi.salud.gob.mx/anuario/html/ anuarios.

[30] Sears R.M., Epidemiology of asthma exacerbations. J Allergy Clin Immunol, 122 (4), pp. 662-668, 2008.

[31] Sáenz, C.L. \& Gutiérrez, B.M., Esporas atmosféricas en la comunidad de Madrid. Industrias Gràficas MAE: Madrid, pp. 9-12, 2003.

[32] Hernández, C.L., Téllez, R.M.M., Sanín, A.L.H., Lacasaña, N.M. Campos, A. \& Romieu, I., Relación entre consultas de urgencias por enfermedad respiratoria y contaminación atmosférica en Ciudad Juárez, Chihuahua. Salud Pública Mex, 42, pp. 288-297, 2000. 